\title{
EFFECT OF PROTEIN STARVATION AND OF PROTEIN FEEDING \\ ON THE CLINICAL COURSE, LIVER FUNCTION, AND LIVER HISTOCHEMISTRY OF THREE PATIENTS WITH ACTIVE FATTY ALCOHOLIC CIRRHOSIS 1, 2
}

\author{
BY RICHARD D. ECKHARDT,3 NORMAN ZAMCHECK, 3 RICHARD L. SIDMAN, \\ GEORGE J. GABUZDA, JR.,3 AND CHARLES S. DAVIDSON \\ (From the Thorndike Memorial Laboratory, Second and Fourth Medical Services [Harvard], \\ Boston City Hospital, and the Department of Medicine, Harvard Medical School, Boston)
}

(Received for publication August 18, 1949)

Experimental studies in animals have demonstrated that the functional and morphologic integrity of the liver depends largely upon the provision of adequate protein and of other lipotropic substances in the diet $(1-4)$. Although the role of dietary protein in liver disease in man has been difficult to evaluate, a nutritious diet is generally accepted as the basic therapeutic consideration (5). It was reported recently from this laboratory, however, that improvement in active liver disease appeared to be as marked in a patient in negative nitrogen balance while receiving insufficient amino acids by vein, as in three other patients given sufficient amino acids to achieve positive nitrogen balance (6). In addition, Popper et al. observed that recovery from acute infectious hepatitis was associated with a gradually decreasing negative nitrogen balance, and was unrelated to the quantity of dietary nitrogen provided (7). We also have observed patients with acute liver disease ( infectious hepatitis, fatty alcoholic cirrhosis) improve clinically and by liver function tests before their desire for food appeared and while their dietary intakes were grossly inadequate.

To clarify the role of protein in the treatment of human liver disease, three deeply jaundiced pa-

1 A preliminary report of this investigation was included in the Proceedings of the Forty-First Annual Meeting of the American Society for Clinical Investigation, May 2, 1949.

2 The expenses of this investigation were defrayed in part by grants from Merck \& Co., Inc., Rahway, New Jersey, and from the Commission on Liver Disease, Army Epidemiological Board, Office of the Surgeon General, U. S. Army, Washington, D. C., to Harvard University.

3 U. S. Public Health Service Postdoctorate Research Fellow.

4 Volunteer Fellow in the Thorndike Memorial Laboratory, Boston City Hospital, and the Department of Anatomy, Harvard Medical School. tients with active fatty alcoholic cirrhosis were provided with food adequate in calories but not sufficient in protein to maintain nitrogen equilibrium. Each patient was then provided with an adequate and nutritious diet for a second period of study. The effect of protein starvation and of protein feeding on the clinical course, liver function, and liver histochemistry of these patients is reported in this communication.

\section{MATERIALS AND METHODS}

The three patients selected each gave a history of longstanding alcoholism, and were deeply jaundiced and acutely ill at the time the study was begun. Patient J. S. was a 39-year-old male who admitted to drinking at least two to four quarts of beer a day for 25 years. During this time he ate a good diet and was regularly employed as a cook. Six weeks before hospitalization, however, his alcoholic intake markedly increased and consisted of hard liquor as well as of beer. $\mathrm{He}$ ate only an occasional sandwich or bowl of soup, and noted that he was jaundiced two days before admission. Patient M. P., a 31-year-old housewife, consumed moderate amounts of whiskey, beer, and wine since she was 17 years old. For the three years preceding the present admission she drank at least a pint to a quart of wine daily, often throughout the day, and ate poorly. She was hospitalized because of jaundice two years before the present admission, and for jaundice and delirium tremens 18 months later. She then gave up drinking entirely until one month before entry, but then began to drink very heavily of wine and ate only an occasional meal. Jaundice was noted two days before the present hospitalization. The third patient, F. C., was a 36-year-old waitress who freely admitted to excessive beer drinking for 12 years. On many occasions her drinking became even heavier and then interfered with her eating. When she noted that she was tremulous, she voluntarily stopped drinking. She was jaundiced seven years before the present admission for a period of one week. Following a five months' abstinence from alcohol, she again began to drink heavily two and one-half months before entry. She noted jaundice five days before hospitalization.

The patients were hospitalized on the Thorndike metabolic ward throughout the study, and were under constant 


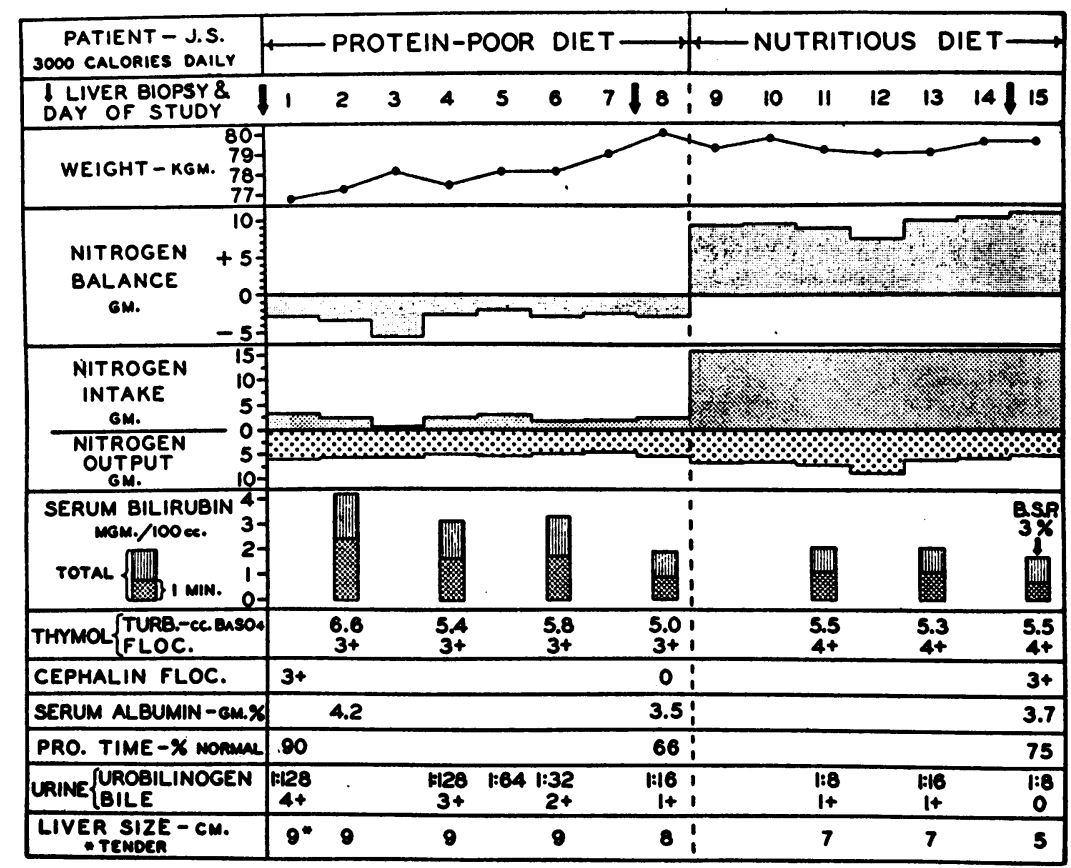

Fig. 1. Effect of Protein Starvation and of a Nutritious Diet on the Nitrogen Balance and Liver Function of Patient J. S.

supervision. During the first period of study each patient was provided with a purified diet adequate in calories but essentially devoid of protein, supplying from 0.2 to 0.4 gram of nitrogen daily as determined by macro-Kjeldahl analysis. The composition of the diet and its ability to maintain nitrogen balance with the addition of adequate amounts of whole protein orally or of hydrolyzed protein intravenously to normal subjects and to patients with liver disease have been described previously $(6,8)$. The diet contained no source of the vitamin B complex except choline in small amounts, estimated to be from 30 to 100 mgm. daily $(9,10)$. A capsule ${ }^{5}$ containing vitamins $A$, $C, D, B_{1}, B_{2}$, niacin, $B_{8}$, and pantothenic acid was given daily. Patients $M$. P. and F. C. received the protein-free diet immediately upon hospitalization. The study of patient J. S. was not begun until the fourth hospital day, although during this time his protein intake was estimated to be under $\mathbf{4 0}$ grams daily. During the first experimental period he received, in addition to the protein-free diet, a vegetable salad, a cup of soup, and two slices of bread each day. This food increased the protein intake to approximately 15 grams daily ( 0.2 gram protein per kilogram of body weight), and the choline intake to roughly $225 \mathrm{mgm}$. daily. Food supplements were not allowed the

5 "Dayamin," furnished through the courtesy of the Abbott Laboratories, North Chicago, Illinois, and containing per capsule: Thiamine hydrochloride $5 \mathrm{mgm}$., riboflavin $5 \mathrm{mgm}$., nicotinamide $25 \mathrm{mgm}$., pantothenic acid $5 \mathrm{mgm}$., pyridoxine $1.5 \mathrm{mgm}$., ascorbic acid $100 \mathrm{mgm}$., vitamin A 10,000 U.S.P. units, and vitamin D 1,000 U.S.P. units. other patients. The nitrogen content of the choline ${ }^{6}$ administered orally to patient F. C. during part of the initial protein-free diet was determined by macro-Kjeldahl analysis. A nutritious diet containing the foods ordinarily eaten in a well-balanced diet was supplied each patient during the second period of study. The nitrogen content was calculated from standard food tables $(11,12)$, and the diet provided at least 1.1 grams of protein per kilogram of body weight daily.

The daily urine and pooled stool nitrogen analyses were determined by the standard micro- or macro-Kjeldahl methods. As measurements of liver function, the serum bilirubin (13), thymol turbidity (14) and flocculation, cephalin cholesterol flocculation (15), plasma prothrombin concentration (16), per cent retention of intravenously administered bromsulphalein dye (5 mgm. per kilogram of body weight at 45 minutes), and urine urobilinogen and bile were determined. The serum albumin concentration was determined in J. S. and M. P. by the Howe method of protein separation (17) and in F. C. by an immunological method employing anti-human serum albumin horse serum (18).

Liver tissue was obtained from each patient by punch biopsy before and during the protein starvation period and during the increased protein feeding period. The biopsies were performed approximately four hours after breakfast. The "Vim"-Silverman needle was employed,

- "Choline Chloride Solution," supplied by the Abbott Laboratories, North Chicago, Illinois.

7 Determined at the Boston City Hospital Surgical Research Laboratory, Dr. Stephen J. Maddock, Director. 
and an anterior approach beneath the lowest rib margin at the midclavicular line, or a posterior approach through the diaphragm at the ninth intercostal space at the posterior axillary line was used. It was intended that the same biopsy site be used in the same patient, but the decrease in liver size in patient F. C. necessitated changing from an anterior to a posterior approach for the last two biopsies. To obtain adequate tissue for study, the needle was usually reinserted to obtain two pieces of tissue each measuring approximately $2 \mathrm{~mm}$. in width and from 2 to $3 \mathrm{~cm}$. in length. There were no untoward effects from these multiple biopsy procedures, save for transient local pain, occasionally radiating to the right shoulder. The following fixatives and staining procedures were employed.

1. Fat. No specific fat stains were used. Neutral fat was easily identified in the liver cells as large, nonstaining vacuoles remaining after passage of the tissue through fat solvents. Estimation of fat was made from the formalin-fixed tissue (routine sections) as well as from the pentose nucleic acid, glycogen, and alkaline phosphatase sections.

2. Pentose nucleic acid. Tissues were fixed in Zenker's fluid and stained with methylene blue and eosin. Of the variety of basophilic substances which are stained by methylene blue, only pentose nucleic acids are known to occur in the cytoplasm of the liver parenchymal cells (19, 20). In this report, the alteration in the cellular content of pentose nucleic acid (frequently designated as ribonucleic acid) is considered an index of the protein content of the liver. The evidence relating nucleic acids to protein synthesis has been reviewed by others $(21,22)$.
3. Glycogen. Tissues were fixed in Rossman's fluid (picric acid-alcohol-formalin) at $0^{\circ} \mathrm{C}$. to ensure an even distribution of glycogen (23). Following hydrolysis of the glycogen molecule with periodic acid, the exposed aldehyde groups were stained with Schiff's leucofuchsin reagent (24). Control sections were treated with saliva for 30 minutes prior to staining.

4. Alkaline phosphatase. Tissues were fixed in cold 80 per cent alcohol, and the enzyme demonstrated by the Gomori technique (25). Fructose diphosphate was used as the substrate since Deane has shown fructose diphosphatase to be the most widely distributed alkaline phosphatase in the livers of a variety of species (26). Sections of each tissue were incubated in the substrate for three, six, and 24 hours.

5. For routine pathological examination, a sample from each biopsy was fixed in 10 per cent formalin and stained with hematoxylin and eosin.8

\section{RESULTS}

The effect of protein starvation and of a nutritious diet upon the nitrogen balance and liver function of the three patients is shown in Figures 1-3.

The nitrogen balance was persistently negative during the initial period while J. S., M. P., and

8 The authors are indebted to the staff of the Mallory Institute of Pathology, Boston City Hospital, for the preparation and staining of the formalin-fixed liver tissue.

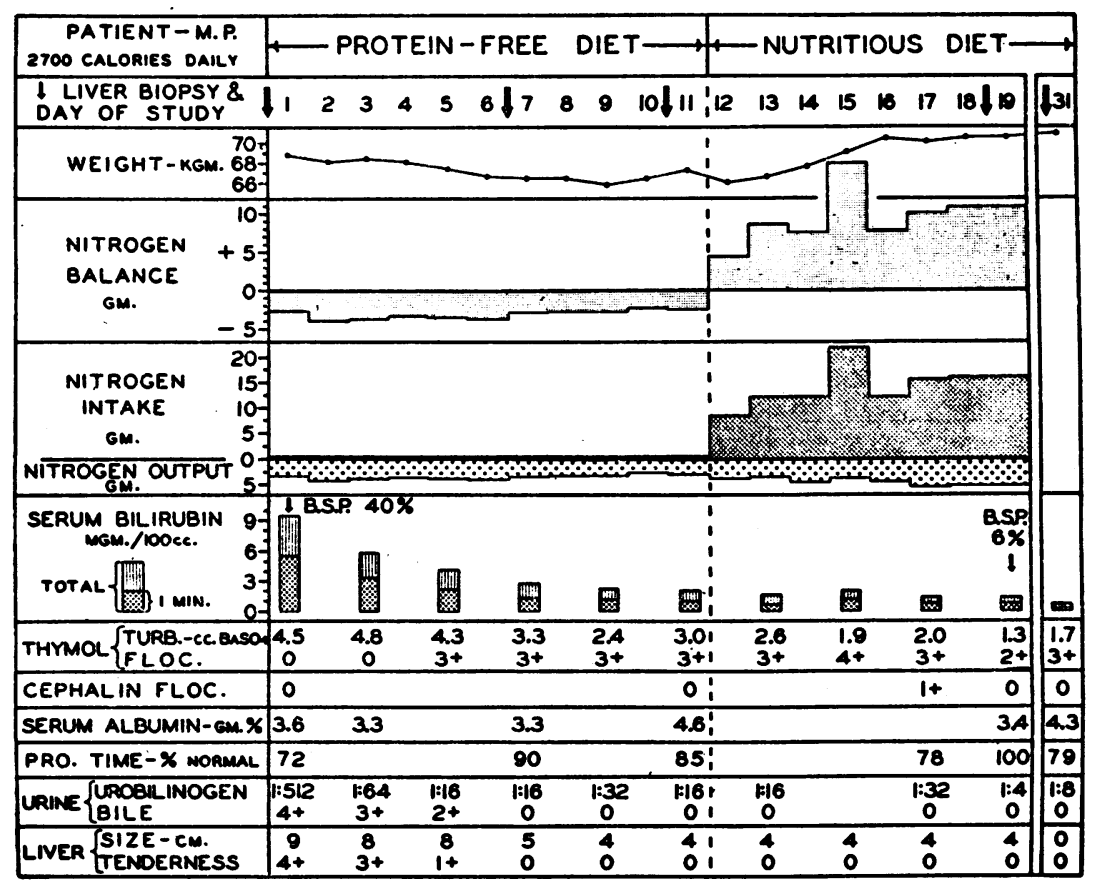

Fig. 2. Patient M. P.

(See legend for Figure 1.) 


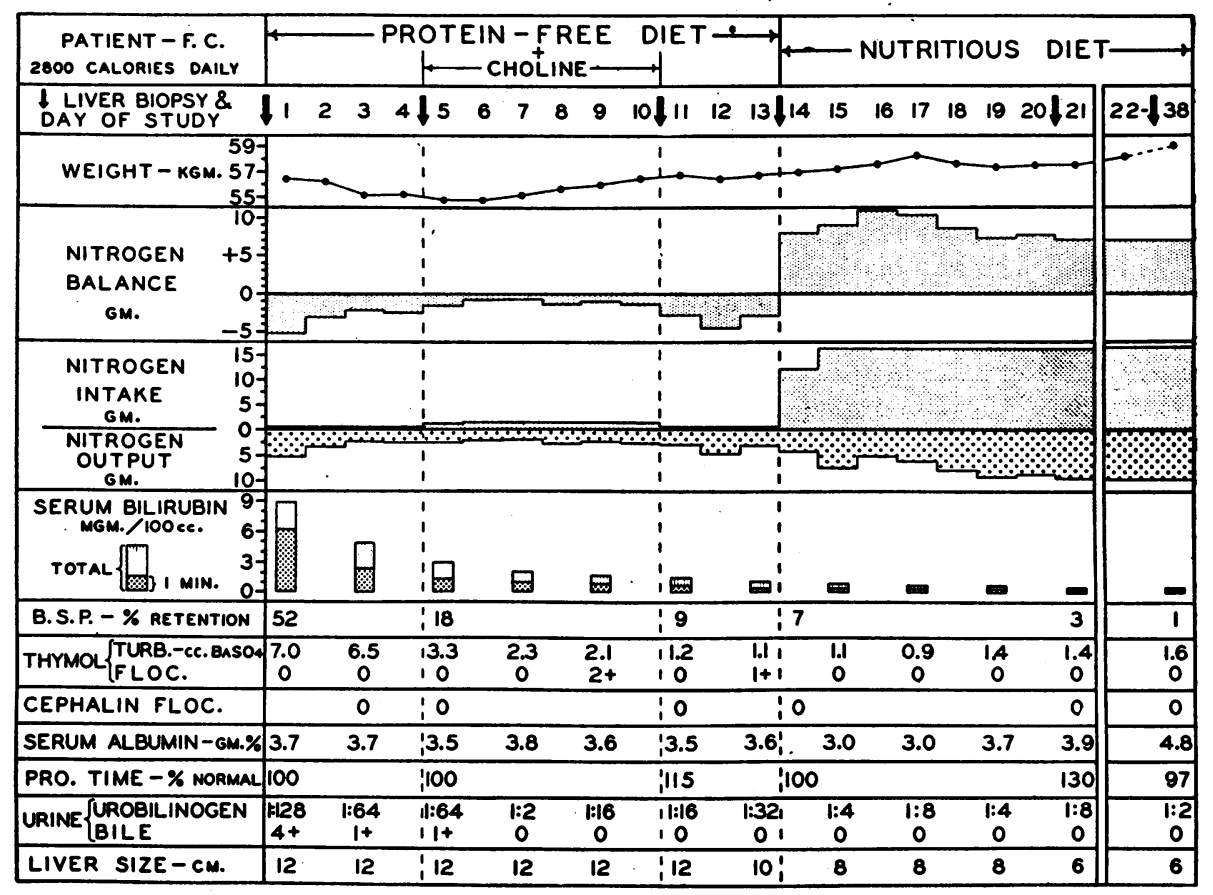

Fig. 3. Patient F. C.

(See legend for Figure 1.)

F. C. received the diets grossly deficient in or devoid of protein for eight, 11 , and 13 days, respectively. The negative nitrogen balance decreased moderately when F. C. was given 12 grams of choline chloride orally daily during part of the protein-free diet period. This decrease represented the quantity of nitrogen ( 1.2 grams) contained in the choline. Nitrogen balance became positive only when the patients were provided with the nutritious diet containing approximately 100 grams of protein daily, and averaged $+9.5,+9.8$, and + 7.6 grams daily for J. S., M. P., and F. C., respectively.

Because of the short duration of these studies, the fluctuations noted in the patients' body weights (Figures 1-3) are difficult to evaluate. Edema and ascites were not discernible in any of the patients.

A marked improvement in liver function was observed for each patient during the initial protein starvation period (Figures 1-3). ${ }^{9}$ There was a

${ }^{9}$ Although $\mathrm{J}$. S. received an inadequate diet for the three days preceding the study, the liver already had decreased $2 \mathrm{~cm}$. in size (from 11 to $9 \mathrm{~cm}$.) and had become less tender, the icteric index had fallen from 75 to 50 units, and the urine urobilinogen had decreased from $1: 512$ to $1: 128$. pronounced and rapid fall in the total serum bilirubin from 4.2 to $1.9 \mathrm{mgm}$. per cent for J. S., from 9.5 to $2.1 \mathrm{mgm}$. per cent for M. P., and from 8.9 to $1.1 \mathrm{mgm}$. per cent for F. C. The marked decrease in the retention of bromsulphalein dye, measured serially in F. C., paralleled that of the serum bilirubin. The most marked changes in both of these tests occurred in this patient prior to the administration of choline. The urine urobilinogen and bile, initially abnormal and elevated for each patient, also progressively decreased toward or to normal during this period. Changes in the thymol turbidity were variable. The values were elevated for each patient at the start of the study (normal value below $1.7 \mathrm{cc} . \mathrm{BaSO}_{4}$ ), and declined to normal in F. C., decreased slightly in M. P., and remained unchanged in J. S. There was a decrease in liver size and tenderness (not present in F. C.) while the patients received the diets containing insufficient protein to maintain nitrogen balance. Improvement in liver function continued for each patient when adequate dietary protein was provided and positive nitrogen balance was achieved. Because of the extent of previous change, however, the further improvement with the nutritious diet appeared less marked than that 
during the protein-deficient period. The thymol and cephalin flocculation tests, serum albumin concentration, and prothrombin time showed no consistent pattern of change during either period of study.

In addition to the markedly improved liver function observed during the initial period in which nitrogen balance was persistently negative, each patient manifested a definite clinical improvement. This was evidenced by increased physical and mental activity and an enhanced sense of wellbeing. Although the patients were permitted un-

TABLE I

Effect of protein starvation and of a nutritious diet upon nitrogen balance, serum bilirubin concentration, and liver content of fat, pentose nucleic acid, and glycogen in three patients with fatty alcoholic cirrhosis

\begin{tabular}{|c|c|c|c|c|c|c|}
\hline \multirow{2}{*}{\multicolumn{2}{|c|}{ Day of study and condition of study }} & \multirow{2}{*}{$\begin{array}{c}\text { Nitrogen } \\
\text { balance } \\
\text { (average) } \\
\text { gm./day }\end{array}$} & \multirow{2}{*}{$\begin{array}{c}\text { Total serum } \\
\text { bilirubin } \\
m g m . / 100 \mathrm{cc} .\end{array}$} & \multicolumn{3}{|c|}{ Liver histology* } \\
\hline & & & & $\begin{array}{c}\text { Fat } \\
0 \text { to } 4+\end{array}$ & $\begin{array}{l}\text { "Protein" } \\
0 \text { to } 4+\end{array}$ & $\begin{array}{l}\text { Glycogen } \\
0 \text { to } 4+\end{array}$ \\
\hline \multirow{3}{*}{ J.S. } & $\stackrel{1}{\text { Control }}$ & - & 4.2 & $2+$ & $2+$ & $2+$ \\
\hline & \begin{tabular}{|l} 
After seven \\
poor diet
\end{tabular} & -3.1 & 1.9 & $2+$ & $1+$ & $4+$ \\
\hline & \begin{tabular}{ccc|} 
After & 15 & \\
diet & days & nutritious
\end{tabular} & +9.5 & 1.7 & \pm & $3+$ & $3+$ \\
\hline \multirow{5}{*}{ M. P. } & $\stackrel{1}{\text { Control }}$ & - & 9.5 & $4+$ & $2+$ & $2+$ \\
\hline & $\begin{array}{c}7 \\
\text { After six days protein-free } \\
\text { diet }\end{array}$ & -3.5 & 2.8 & $4+$ & $1+$ & $3+$ \\
\hline & $\begin{array}{l}11 \\
\text { After ten days protein-free } \\
\text { diet }\end{array}$ & -2.6 & 2.1 & $4+$ & \pm & - \\
\hline & $\begin{array}{c}19 \\
\begin{array}{c}\text { After seven days nutritious } \\
\text { diet }\end{array}\end{array}$ & +9.8 & 1.4 & $3+$ & $2+$ & - \\
\hline & 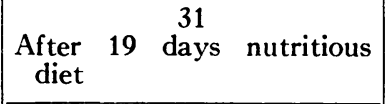 & (Home) & 0.6 & $2+$ & $3+$ & $4+$ \\
\hline \multirow{6}{*}{ F. C. } & $\begin{array}{c}1 \\
\text { Control }\end{array}$ & 一 & 8.9 & $3+$ & $2+$ & $2+$ \\
\hline & $\begin{array}{c}5 \\
\text { After four days protein-free } \\
\text { diet }\end{array}$ & -2.5 & 3.0 & $3+$ & $2+$ & $3+$ \\
\hline & $\begin{array}{c}11 \\
\text { After ten days protein-free } \\
\text { diet+six days choline }\end{array}$ & -1.0 & 1.5 & $2+$ & $1+$ & $4+$ \\
\hline & $\begin{array}{c}\text { After } 13 \text { days protein-free } \\
\text { diet }\end{array}$ & -3.3 & 1.1 & $\dagger$ & - $\cdot$ & - \\
\hline & $\begin{array}{l}21 \\
\text { After seven days nutritious } \\
\text { diet }\end{array}$ & +8.7 & 0.5 & $2+$ & 一 & - \\
\hline & $\begin{array}{c}38 \\
\text { After } 24 \text { days nutritious diet }\end{array}$ & +7.1 & 0.6 & \pm & $3+$ & $4+$ \\
\hline
\end{tabular}

* Based on arbitrary normal values of 0 for fat and of $4+$ for protein and glycogen. $\dagger$ Insufficient tissue for adequate examination. 

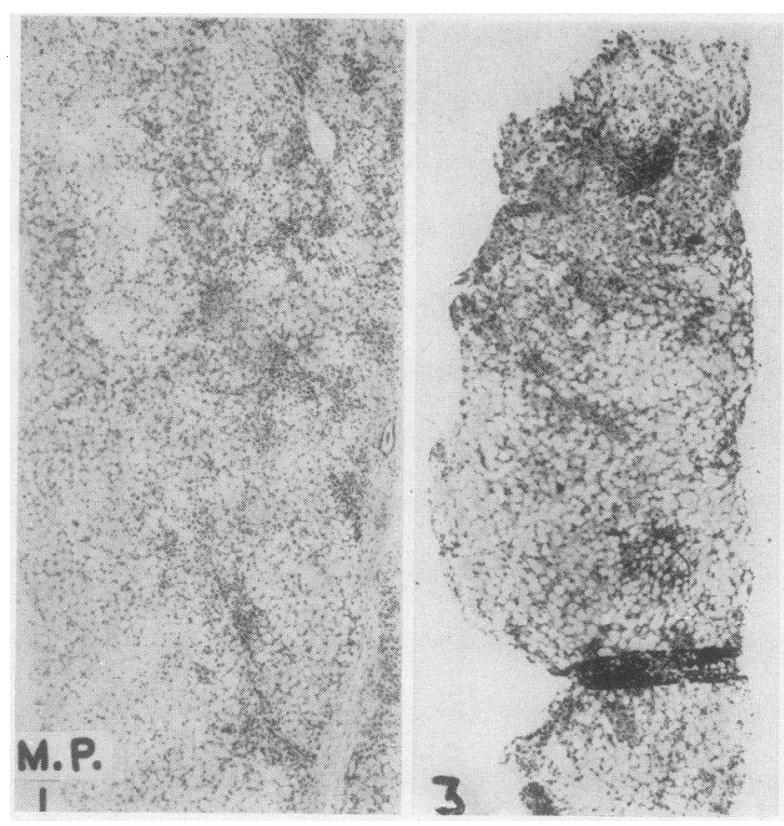

FIG. 4.

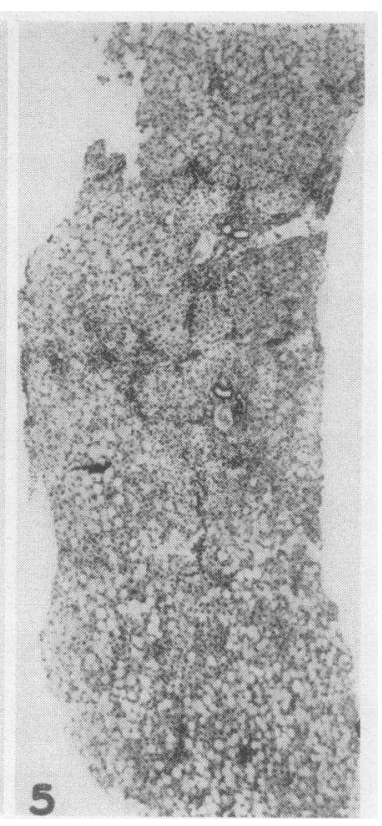

5

.

The liver fat is seen as non-staining vacuoles in the cell cytoplasm. The liver of M. P. initially contained large amounts of fat. This remained unchanged after the protein-free diet was given for ten days (Biopsy No. 3), and decreased moderately after the nutritious diet was provided for 19 days (Biopsy No. 5). $\times 30$.

restricted activity, they were too ill when the study was begun to participate in the usual ward activities. By the end of the protein starvation period, however, they were considerably more active and were up and about the ward throughout the day, assisting in making beds and cleaning their rooms. After several days the anorexia initially present had completely abated, and with the return of appetite each expressed a manifest dislike for the purified diet and pleaded for more substantial food. After the conclusion of the protein starvation regime, the subjects ate very well of the normal diet containing approximately 100 grams of protein daily. Patient J. S. was discharged on the 19 th, and M. P. on the 21 st hospital day. ${ }^{10}$ The study of F. C. was completed by her 21 st hospital day, by which time the tests of liver function were within the limits of normal. She voluntarily remained on the ward for three more weeks for additional metabolic studies.

The results of histochemical studies of liver tissue obtained by biopsy from the three patients be-

\footnotetext{
10 Patient M. P. continued to eat a nutritious diet and to abstain from alcohol after discharge, and was readmitted in ten days for a final liver biopsy.
}

fore and during the protein starvation period and during the increased protein feeding period are presented in Table I and described below. ${ }^{11}$ Photomicrographs of liver tissue from individual patients illustrating representative changes in morphology are shown in Figures 4-7.

1. Fat. The initial biopsies revealed a moderate to marked content of fat which appeared as variably sized vacuoles distending the parenchymal cells. No significant change was seen during the period of protein deprivation. Liver fat decreased moderately during the oral supplementation of

11 The interpretation of the liver sections was subject to certain limitations, principally that imposed by the small size of the sample of tissue obtained. Histochemical techniques can not, as yet, be adequately quantitated, especially with a tissue as heterogeneous as the pathological liver, and the "quantitative" values listed in Table I are to be considered as only rough approximations. To minimize the factor of biopsy size, two samples of tissue were usually obtained at each biopsy. All biopsies were performed four hours after breakfast to assure a uniformity of factors of food intake, time of day, and state of activity. To reduce the sampling error, the same site was chosen for biopsy in the same patient, whenever possible. The final interpretation was the result of independent examinations of unmarked slides by the authors. 
the protein-free diet with 12 grams of choline chloride daily for six days in patient F. C. After receiving the nutritious diet containing approximately 100 grams of protein daily, all patients showed an extensive decrease in fat content con- sisting of a decrease in the size and number of fat vacuoles.

2. Pentose nucleic acid. In all subjects there was an initial low concentration of pentose nucleic acid granules which were distributed about
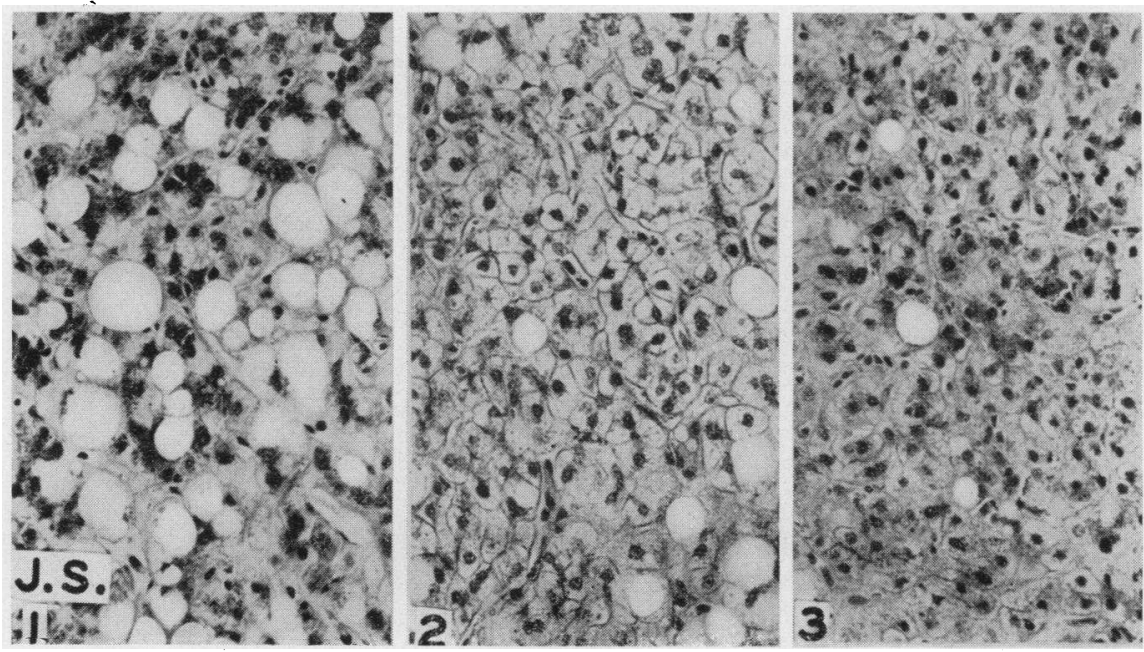

FIG. 5.

Pentose nucleic acid appears as dark-staining granules in the cytoplasm of the liver cells. These granules in the initial liver biopsy of J. S. were clustered in moderate amounts in some cells, but were deficient in others (Biopsy No. 1). After receiving the diet deficient in protein for seven days, pentose nucleic acid was depleted in all cells (Biopsy No. 2). After six days of increased protein feeding, there was a return of the granules which were uniformly distributed throughout the cell cytoplasm (Biopsy No. 3). $\times 160$.
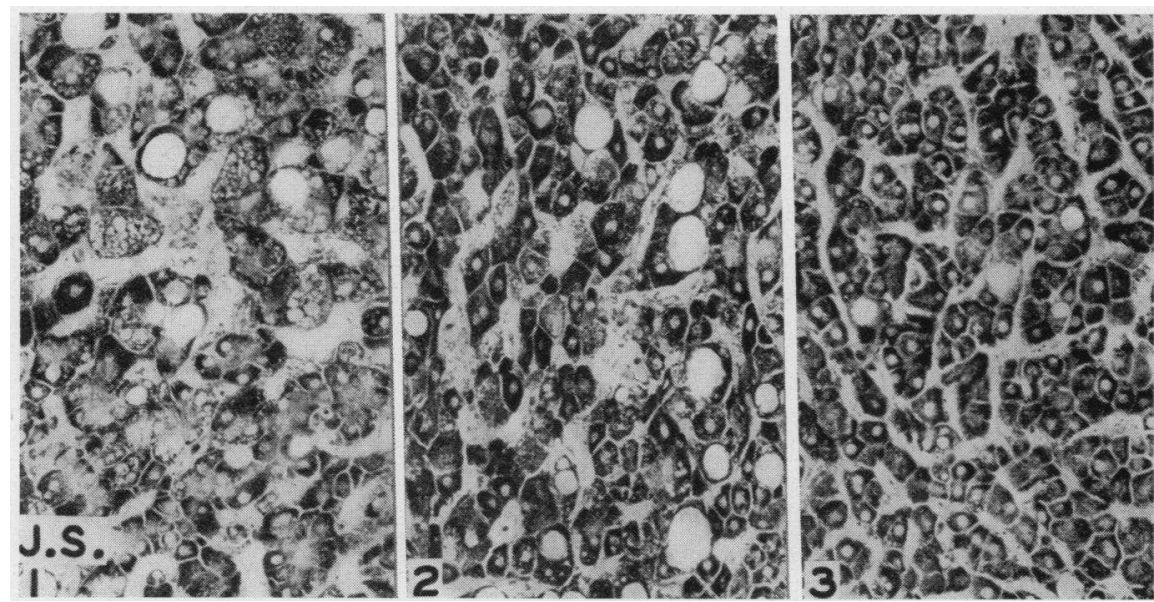

FIG. 6.

The glycogen in this preparation appears as dark-staining material in the cell cytoplasm, and fat is seen as clear vacuoles of varying size. The cell nuclei are not stained. The moderate quantity of glycogen initially present in the liver of J. S. (Biopsy No. 1) increased after the patient received an adequate caloric but protein-poor diet for seven days (Biopsy No. 2). Liver glycogen, although slightly decreased, remained abundant after six days of the 100 gram protein diet (Biopsy No. 3). $\times 160$. 


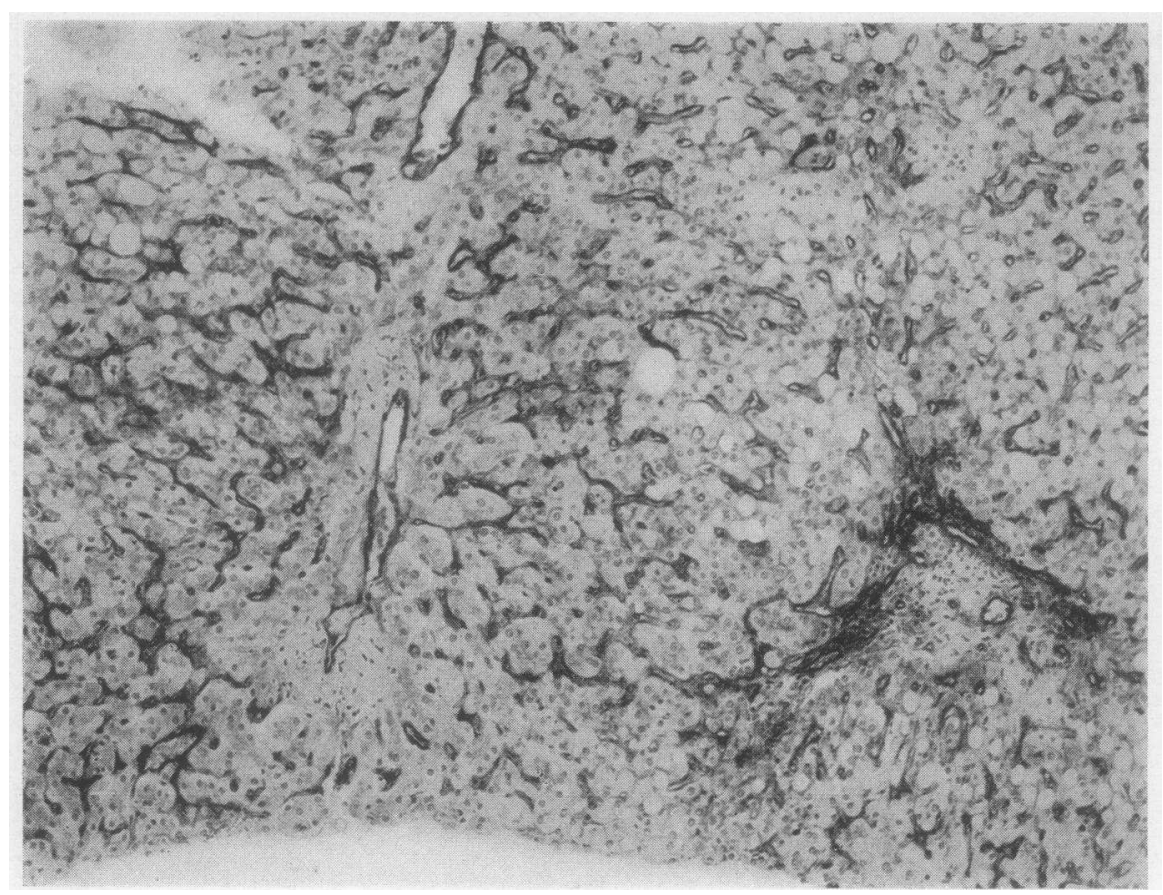

FIG. 7.

The distribution of alkaline phosphatase in the initial liver biopsy of F. C. is shown in this preparation of tissue incubated for six hours in fructose diphosphate substrate. The enzyme was found in Kupffer cells, in the sinusoidal and blood vessel linings, and in bile canaliculi. $\times 100$.

the nuclei or clumped around the bile canaliculi. During the period of negative nitrogen balance, and including the period in which F. C. received choline in addition to the protein-free diet, the initial low cellular pentose nucleic acid content was further diminished in every instance. After the nutritious diet was provided and positive nitrogen balance was achieved, there was a progressive increase in pentose nucleic acid. The clumping of granules then was replaced by a uniform cytoplasmic distribution.

3. Glycogen. The histologic findings were similar for each subject. The moderate quantity of glycogen initially present in the liver parenchymal cells increased during the protein-deficient diet period. In the second period when adequate dietary protein was provided the liver cells remained filled with glycogen.

4. Alkaline phosphatase. The enzyme was localized mainly in the Kupffer cells, sinusoidal and blood vessel linings, and bile canaliculi. No consistent changes in content or distribution were noted during either period of study.
5. Gencral morphology. All liver biopsy sections showed minimal to moderate fibrosis of the portal areas which did not change significantly during the course of the study. Necrosis was not observed. The individual cells of the initial biopsies showed marked variation in size and shape. During the protein-deficient diet period, the nonfat containing cells appeared more swollen and rounded. When adequate exogenous protein was provided and positive nitrogen balance was achieved, the cellular appearance returned toward normal. Distended bile canaliculi, occasionally seen in the initial biopsies, were less frequent in later sections.

\section{DISCUSSION}

It was observed in this study that each of three deeply jaundiced patients with active fatty alcoholic cirrhosis exhibited marked improvement in clinical status and in liver function while in negative nitrogen balance occasioned by diets containing only $0.2,0.0$, and 0.0 gram of protein per kilogram of body weight daily for eight, 11, and 
13 days, respectively. Similar changes were observed previously in a patient given insufficient amino acids by vein and in negative nitrogen balance for 24 days (6). Since the diets in each instance were either grossly deficient in or devoid of protein and supplied only small amounts of choline, the improvement noted could not be attributed to exogenous protein or lipotropic substances. It was previously conjectured that the improved liver function might have resulted from mobilization of tissue proteins to the liver (6), since other studies demonstrated that tissue repair could take place during periods of insufficient dietary protein intake and negative nitrogen balance by the diversion of nitrogen from one organ of the body to another $(27-30)$. This did not appear to be the case, since liver histology failed to reflect the clinical and functional improvement.

The factors responsible for the improvement in clinical status and in liver function noted in these patients are not defined, except to demonstrate the subsidiary role of protein and of lipotropic substances. Additional studies will be required to determine the relative importance of withdrawal of alcohol, of diminished physical activity and increased bed rest, of improved hydration, of dietary factors other than protein and choline (calories, vitamins), and perhaps of other yet unknown factors. Because of the rapidity of improvement noted in these patients, it would be difficult to ascertain whether improvement could be more promptly achieved by an adequate rather than by an inadequate protein intake, or by diets containing supplements of additional protein or of lipotropic substances. In fact, the jaundice in patient M. P. subsided as promptly at the present admission as at two previous hospitalizations at which time she received a nutritious high-protein diet with added vitamins and liver extract, although the initial icterus in each instance was of comparable degree.

The favorable results reported here occurred in acutely ill and markedly jaundiced patients with fatty (alcoholic) liver disease. Patients with acute infectious hepatitis, likewise, may exhibit an uneventful recovery even though provided with insufficient protein and in negative nitrogen balance (7). This observation by Popper et al. confirms our clinical impression that patients with acute infectious hepatitis may improve while eating grossly inadequate diets, and that their enhanced desire for food may appear only after they have demonstrated improvement clinically and by liver function tests.

Histologic improvement in the liver occurred in two instances: First, with the provision of adequate exogenous protein and the maintenance of a positive nitrogen balance, the liver tissue in each patient showed a marked increase in protein content, a progressive decrease in fat, and a return of cell size and appearance toward normal. Second, in one patient, choline administration (12 grams choline chloride orally daily for six days) was accompanied by a moderate decrease in liver fat. However, the other morphologic changes were unaltered from those noted in the other patients while receiving only the protein-deficient diets. Because the tests of liver function had improved so markedly before either the nutritious diet or choline was given, it was not possible to attribute the patients' continued, although less dramatic, improvement to the changes in liver histology.

The increase in the parenchymal cell glycogen content observed during the period of negative nitrogen balance in all subjects can fairly be attributed to the high caloric and carbohydrate diet provided. The increase in cellular glycogen possibly accounted for the more rounded appearance of the non-fat containing liver cells during protein starvation. Cellular necrosis did not occur during this short period. Hepatic fibrosis remained essentially unchanged throughout both periods of study, as did liver alkaline phosphatase. The significance of this latter observation is difficult to evaluate because of the limited data available concerning the role of this enzyme in human liver.

The persistence in the liver of a low cellular protein content, abundant fat, and abnormality of cellular appearance during the period of deficient protein intake and negative nitrogen balance, contrasts sharply with the rapid improvement noted in clinical status and in liver function. This contrast might have been less dramatic had other tests been utilized, for some of the many functions of the liver might not have improved, and perhaps might have been adversely affected. Similarly, the failure to observe histologic liver improvement during this period does not exclude the possibility that other histological procedures might have shown improvement. The diversified 
activities of the liver cannot yet be fully exposed by either functional or histochemical tests, and it is conceivable that the activities most directly related to the well-being of the patient were not under investigation at all.

The results of the present study can not be considered at variance with the studies previously reported in animals and in man concerning the role of dietary protein in liver disease. It must be emphasized that our patients received the protein starvation diets for only short periods of time. The effect of more prolonged protein deprivation on liver function and histology in man can merely be conjectured. Such a study would appear unwise in view of the demonstrated adverse effects upon the functional and morphologic integrity of the livers of experimental animals provided with diets low in protein for protracted periods of time $(1-4)$. The present study, however, demonstrates that the provision of diets grossly inadequate in protein for short periods of time to patients with acute liver disease (fatty alcoholic cirrhosis) does not militate against improvement in clinical status and in liver function. Because of the rapidity of change that may occur in acute liver disease, together with the individual variability that exists among patients, it is necessary to exercise caution in assessing the efficacy of a single therapeutic agent unless adequate control studies are simultaneously provided.

\section{SUMMARY AND CONCLUSIONS}

1. Three deeply jaundiced patients with active fatty alcoholic cirrhosis were selected for a study of the effect of protein starvation and of subsequent re-feeding upon their clinical course, liver function, and liver histochemistry.

2. During an initial protein starvation period the subjects were provided with food adequate in calories but not sufficient in protein to maintain nitrogen equilibrium $(0.2,0.0$, and 0.0 gram of protein per kilogram of body weight daily for eight, 11 , and 13 days, respectively). During part of this period, one patient received orally 12 grams of choline chloride daily for six days. During a subsequent nutritious diet period, the subjects received at least 1.1 grams of protein per kilogram of body weight daily for six, 19 , and 24 days, respectively.

3. During protein starvation, although the ni- trogen balance was persistently negative, each patient manifested clinical improvement, a decrease in liver size and tenderness (not present in one patient), a rapid fall in serum bilirubin, in urine bile, and in bromsulphalein retention (measured serially in only one patient), and a progressive decrease in urine urobilinogen. The most marked changes in these tests preceded choline administration to one patient. Nine liver punch biopsies during the protein starvation period showed moderate to marked fat which remained unaltered except for a moderate decrease during choline administration, an initial low cellular protein content which further diminished, and a moderate cellular glycogen content which progressively increased. Necrosis was not observed.

4. During the increased protein feeding period a marked positive nitrogen balance was attained. Improvement in clinical status and in liver function continued but appeared less marked than that during the protein-deficient diet because of the extent of previous change. Five liver punch biopsies obtained during the protein feeding period showed a progressive decrease in fat, a marked increase in protein content, and a return of cell size and appearance toward normal. Liver glycogen remained abundant. Hepatic fibrosis (minimal) and alkaline phosphatase remained unchanged during both periods of study.

5. It is concluded that, under the conditions of this study, improvement in clinical status and in liver function occurred in spite of negative nitrogen balance occasioned by diets grossly deficient in or devoid of protein. Liver histology, however, failed to reflect this improvement, and except for a moderate reduction in liver fat during choline administration, morphologic improvement appeared only with the provision of adequate exogenous protein and the maintenance of positive nitrogen balance.

\section{ACKNOWLEDGMENTS}

The authors wish to thank Dr. Edward Dempsey and Dr. Helen Deane, Department of Anatomy, Harvard Medical School, for critically evaluating the histochemical data presented in this paper; Mrs. Edith Herman, Department of Anatomy, Harvard Medical School, and Miss Lillian Leavitt, Mallory Institute of Pathology, Boston City Hospital, for preparing the pathological material; the Misses Atice Ballou, Beatrice Bernstein, Ellen Doyle, and Carol Roland, Thorndike Memorial Laboratory, Bos- 
ton City Hospital, for technical assistance; and Miss Kathleen Clinton, dietitian, Thorndike Memorial Laboratory, Boston City Hospital, for preparing and calculating the diets used.

\section{BIBLIOGRAPHY}

1. György, P., Experimental hepatic injury. Am. J. Clin. Path., 1944, 14, 67.

2. Himsworth, H. P., and Glynn, L. E., Massive hepatic necrosis and diffuse hepatic fibrosis (acute yellow atrophy and portal cirrhosis): Their production by means of diet. Clin. Sci., 1944, 5, 93.

3. Rich, A. R., and Hamilton, J. D., The experimental production of cirrhosis of the liver by means of a deficient diet. Bull. Johns Hopkins Hosp., 1940, 66, 185.

4. Miller, L. L., and Whipple, G. H., Liver injury, liver protection, and sulfur metabolism. Methionine protects against chloroform injury even when given after anesthesia. J. Exper. Med., 1942, 76, 421.

5. Patek, A. J., Jr., and Post, J., Treatment of cirrhosis of the liver by a nutritious diet and supplements rich in vitamin B complex. J. Clin. Invest., 1941, 20, 481.

6. Eckhardt, R. D., Faloon, W. W., and Davidson, C. S., Improvement of active liver cirrhosis in patients maintained with amino acids intravenously as the source of protein and lipotropic substances. J. Clin. Invest., 1949, 28, 603.

7. Popper, H., Kozoll, D. D., Steigman, F., and Mok, W. T., Has methionine a protein sparing effect in acute infectious hepatitis? Am. J. M. Sc., 1948, 215, 624.

8. Eckhardt, R. D., Lewis, J. H., Murphy, T. L., Batchelor, W. H., and Davidson, C. S., Chemical, clinical and immunological studies on the products of human plasma fractionation. XXXIV. Comparative studies on the nutritive value of orally and intravenously administered human serum albumin in man. J. Clin. Invest., 1948, 27, 119.

9. Wohl, M. G., Dietotherapy, Clinical Application of Modern Nutrition. W. B. Saunders Company, Philadelphia, 1945, p. 269.

10. Borglin, N-E., On the excretion of choline in urine. Acta pharmacol. et toxicol., 1947, 3, Suppl. 1, 1.

11. Bridges, M. A., and Mattice, M. R., Food and Beverage Analyses. Lea and Febiger, Philadelphia, 1942 (Second edition).

12. Bowes, A. deP., and Church, C. F., Food values of portions commonly used. Available from Anna dePlanter Bowes, Philadelphia Child Health Society, Philadelphia, 1944 (Fifth edition).

13. Ducci, H., and Watson, C. J., The quantitative determination of the serum bilirubin with special reference to the prompt-reacting and the chloroformsoluble types. J. Lab. \& Clin. Med., 1945, 30, 293.
14. Ley, A. B., Lewis, J. H., and Davidson, C. S., The quantitative determination of the thymol turbidity reaction of serum. J. Lab. \& Clin. Med., 1946, 31, 910.

15. Hanger, F. M., Serological differentiation of obstructive from hepatogenous jaundice by flocculation of cephalin-cholesterol emulsions. J. Clin. Invest., 1939, 18, 261.

16. Rosenfield, R. E., and Tuft, H. S., Estimation of prothrombin level from prothrombin time. Am. J. Clin. Path., 1947, 17, 405.

17. Howe, P. E., The use of sodium sulfate as the globulin precipitant in the determination of proteins in blood. J. Biol. Chem., 1921, 49, 93.

18. Gitlin, D., Davidson, C. S., and Wetterlow, L. H., The estimation of human serum albumin in body fluids by a quantitative immunochemical method using horse antibody. (Submitted for publication.)

19. Davidson, J. N., and Waymouth, C., The histochemical demonstration of ribonucleic acid in mammalian liver. Proc. Royal Soc. Edinburgh, 1944, 62, 96.

20. Deane, H. W., Basophilic bodies in hepatic cells. Am. J. Anat., 1946, 78, 227.

21. Greenstein, J. P., Nucleoproteins in: Advances in Protein Chemistry, Anson, M. L., and Edsall, J. T., Editors. Academic Press, Inc., New York, 1944, Vol. 1, 209.

22. Dempsey, E. W., and Wislocki, G. B., Histochemical contributions to physiology. Physiol. Rev., 1946, 26, 1.

23. Deane, H. W., Nesbett, F. B., and Hastings, A. B., Improved fixation for histological demonstration of glycogen and comparison with chemical determination in liver. Proc. Soc. Exper. Biol. \& Med., 1946, 63, 401.

24. McManus, J. F. A., Histological demonstration of mucin after periodic acid. Nature, 1946, 158, 202.

25. Gomori, G., Microtechnical demonstration of phosphatase in tissue sections. Proc. Soc. Exper. Biol. \& Med., 1939, 42, 23.

26. Deane, H. W., A cytochemical survey of phosphatases in mammalian liver, pancreas and salivary glands. Am. J. Anat., 1947, 80, 321.

27. Heath, C. W., and Taylor, F. H. L., The nitrogen metabolism in anemia during the regeneration of blood. J. Clin. Invest., 1936, 15, 411.

28. Whipple, G. H., Hemoglobin and plasma proteins : Their production, utilization and interrelation. Am. J. M. Sc., 1942, 203, 477.

29. Kobak, M. W., Benditt, E. P., Wissler, R. W., and Steffee, C. H., The relation of protein deficiency to experimental wound healing. Surg., Gynec. \& Obstet., 1947, 85, 751.

30. Vars, H. M., and Gurd, F. N., Effect of dietary protein upon the regeneration of liver protein in the rat. Am. J. Physiol., 1947, 151, 399. 